\title{
Chromosomal Differentiation among Allopatric Populations of Hyphessobrycon anisitsi (Pisces, Tetragonopterinae)
}

\author{
Liano Centofante, Luis Antônio Carlos Bertollo, Carlos Suitoshi Miyazawa \\ and Orlando Moreira-Filho*
}

Universidade Federal de São Carlos, Departamento de Genética, Via Washington

Luis km 235, caixa postal 676, CEP 13565-905, São Carlos, SP, Brasil

Received July 2, 2003; accepted August 1, 2003

\begin{abstract}
Summary Chromosomal data of Hyphessobrycon anisitsi are presented for the first time, comprising 2 populations from adjacent hydrographical basins (Upper Paraná basin and Paraíba do Sul basin), separated by Mantiqueira Hills (water divisor). The same diploid number and karyotype formula were observed in both populations. However, after silver nitrate staining (Ag-NORs) and fluorescent in situ hybridization with $18 \mathrm{~S}$ rDNA and 5S rDNA probes, it was possible to identify each population by the location of ribosomal sites. Some aspects related to geographical isolates and chromosomal differentiation are approached.
\end{abstract}

The Tetragonopterinae are considered the ancestor of Characid fish (Eigenmann 1917). This group is composed by small-sized species, presenting a high degree of endemism and a fast speciation rate, widespread throughout South and Central Americas (Bohlke et al. 1978). They are regarded as an artificial group as several taxonomical and phylogenetical questions are still to be solved (Lucena 1993).

Hyphessobrycon is one of the most specious genus from this subfamily, comprising about 90 described species, which reach up to $60 \mathrm{~mm}$ of total length (Lima and Gerhard 2001). They are characterized by an interrupted lateral line and by the absence of scales in the lobes of the caudal fin (Britski 1972). Several species present a remarkable coloration, being of great interest for aquarium hobbyists.

Little is known about cytogenetical patterns of Hyphessobrycon since very few species have been karyotyped, and most of them report only the haploid chromosomal number (Scheel 1973). However, the chromosomal number is variable amongst species, ranging from $2 n=46$ to $2 n=52$, mostly presenting $2 n=48$ and $2 n=50$ (Scheel 1973, Arefjev 1990, present work).

In the present study, chromosomal data of Hyphessobrycon anisitsi are, for the first time, presented for 2 allopatric populations from adjacent hydrographic basins, separated by a water divisor (Mantiqueira Hills). Some aspects related to allopatry and chromosomal evolution are further discussed.

\section{Material and methods}

Six hundred and forty metaphases of Hyphessobrycon anisitsi (16 females and 13 males) from Piracuama river, a tributary of Paraíba do Sul river $\left(22^{\circ} 43^{\prime} 18^{\prime \prime} \mathrm{S}\right.$ and $\left.45^{\circ} 40^{\prime} 16^{\prime \prime} \mathrm{W}\right)$ and 490 metaphases of Hyphessobrycon anisitsi (12 females and 8 males) from Perdizes stream, a tributary of Sapucaí river, Upper Paraná basin $\left(22^{\circ} 44^{\prime} 43^{\prime \prime} \mathrm{S}\right.$ and $\left.45^{\circ} 34^{\prime} 07^{\prime \prime} \mathrm{W}\right)$, were analyzed. The specimens were classified and kept at the National Museum of Rio de Janeiro, identified, respectively, by the numbers MNRJ22205 and MNRJ22206.

\footnotetext{
* Corresponding author, e-mail: omfilho@power.ufscar.br
} 
The mitotic chromosomal preparations were obtained according to Bertollo et al. (1978). The methodologies described by Sumner (1972) and Howell and Black (1980) were adopted to locate the constitutive heterochromatin and active nucleolar organizer regions (Ag-NORs), respectively, with slight modifications. Sequential banding procedures followed the suggestions presented by Centofante et al. (2002). The chromosomal localization of 18S and 5S rDNA was accomplished by fluorescent in situ hybridization (FISH), as described by Pinkel et al. (1986), using 18S rDNA probe from Parodon hilarii (Vicente 2001) and 5S rDNA probes from Leporinus elongatus (Martins and Galetti Jr. 1999). The chromosomal morphology was determined by arm ratio (Levan et al. 1964).

\section{Results}

The population of Hyphessobrycon anisitsi from Piracuama river presented a diploid number $2 n=50$ chromosomes. The karyotype is composed by 6 metacentric (M) chromosomes, 16 submetacentric (SM) chromosomes, 12 subtelocentric (ST) chromosomes and 16 acrocentric (A) chromosomes, with a fundamental number (FN) equal to 84 . No sex chromosomal heteromorphism was observed (Fig. 1a). The constitutive heterochromatin (C-bands) was evidenced on the pericentromeric region of all chromosomes, plus some conspicuous terminal marks on the short arms of $1^{\text {st }}, 2^{\text {nd }}$, and $6^{\text {th }}$ pairs and on the long arms of the pairs 1, 4, 6, 12, 18, 19, 20, and 21 (Fig. 1b). Up to 4 active nucleolar organizer regions (Ag-NORs) were detected, located on the telomeric region of the long arms of the $14^{\text {th }}$ chromosomal pair and on short arms of 1 homologue from the $1^{\text {st }}$ and $17^{\text {th }}$ pairs (Fig. 1 in box). Fluorescent in situ hybridization with $18 \mathrm{~S}$ rDNA probe allowed to identify 13 chromosomes bearing ribosomal sites (Fig. 3a). When $5 \mathrm{~S}$ rDNA probe was employed, 4 regions were positively signed, 2 of them located at 1 large subtelocentric pair and, the remaining, at 1 medium-sized metacentric pair (Fig. 3c).

The population of $H$. anisitsi from Perdizes stream also presented a diploid number $2 \mathrm{n}=50$ chromosomes and the karyotype was composed by $6 \mathrm{M}+16 \mathrm{SM}+$ $12 \mathrm{ST}+16 \mathrm{~A}$ as well, with a fundamental number (FN) equal to 84 (Fig. 2a). Similarly to the population from Piracuama river, no sex chromosomal differentiation was indicated. C-bands were evidenced over pericentromeric region of all chromosomes, with some terminal blocks on the short arms of the pairs 1,2, and 6 and on the long arms of the pairs 1, 4, 8, 10, 12, 18, 19, 20, and 21 (Fig. 2b). Up to 3 active Ag-NORs were identified, on the telomeric region of the long arms at $8^{\text {th }}$ pair and on the telomeric region

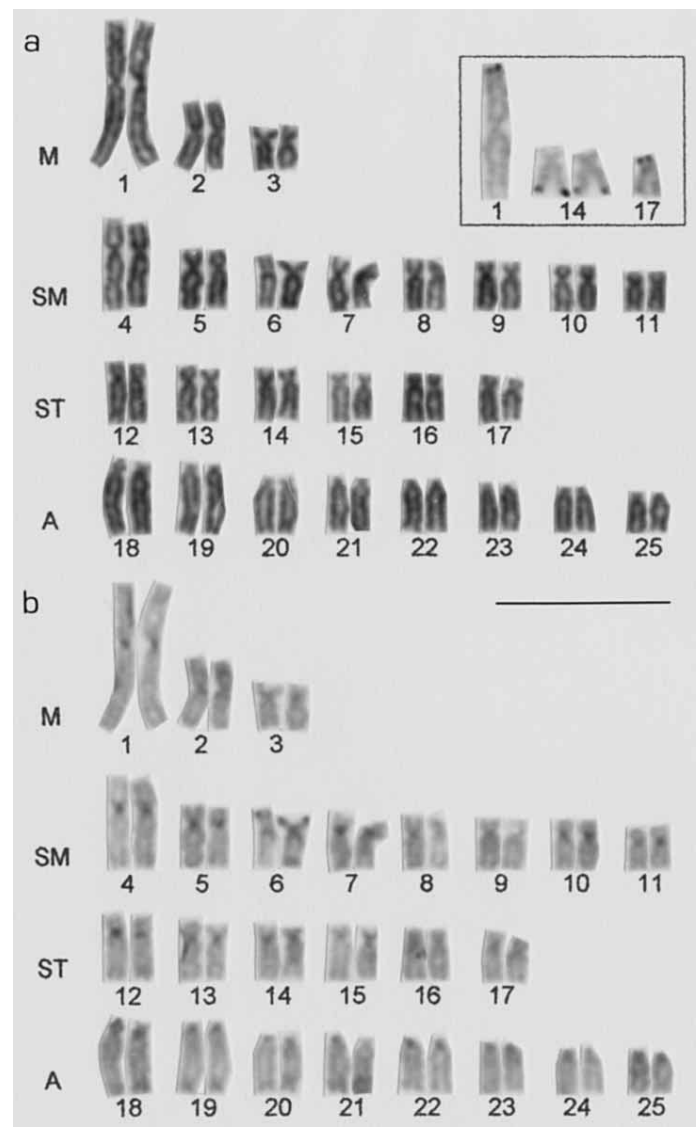

Fig. 1. Karyotype of Hyphessobrycon anisitsi from Piracuama river. a) conventional Giemsa staining, b) C-banding, in box) chromosomes bearing Ag-NORs. The bar is equal to $5 \mu \mathrm{m}$. 
of the short arm at 1 homologue from the $19^{\text {th }}$ pair (Fig. 2 in box). By fluorescent in situ hybridization, 10 sites of $18 \mathrm{~S}$ rDNA (Fig. 3b) and 5 of $5 \mathrm{~S}$ rDNA were identified, the latter ones located at one large subtelocentric pair, 1 medium-sized metacentric pair, and at 1 medium-sized subtelocentric chromosome, always on long arms and close to centromere (Fig. 3d).

\section{Discussion}

Cytogenetical studies in fish have demonstrated that populations separated by geographical barriers are more susceptible to the fixation of chromosomal alterations. The populations of $H$. anisitsi analyzed in the present work are isolated from each other by the Mantiqueira Hills, a water divisor derived from geomorphological events during Tertiary (Ab'Saber and Bernardes 1956). These populations presented a same diploid number and karyotypical formula, as well as a similar pattern of constitutive heterochromatin distribution (C-band). However, both populations showed distinct and characteristic patterns regarding to number and location of ribosomal genes. Therefore, Ag-NORs were located at the $14^{\text {th }}$ pair, at 1 homologue from the first pair, and at the $17^{\text {th }}$ pair in the population from Piracuama river, what was confirmed by

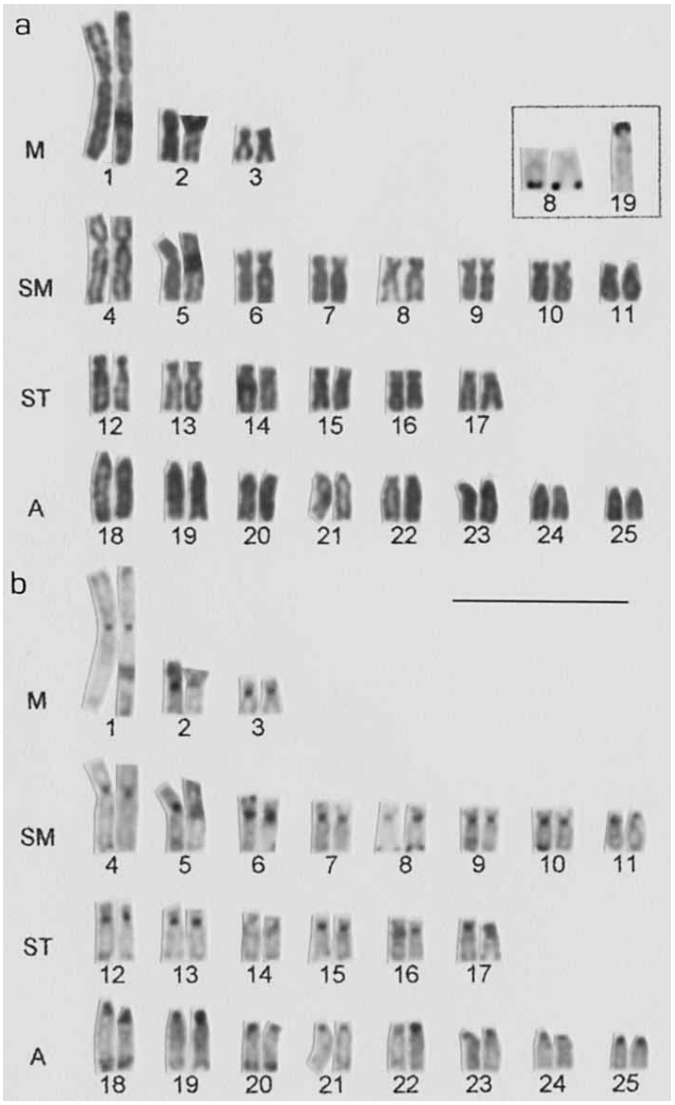

Fig. 2. Karyotype of Hyphessobrycon anisitsi from Perdizes stream. a) conventional Giemsa staining, b) Cbanding; in box) chromosomes bearing Ag-NORs. The bar is equal to $5 \mu \mathrm{m}$.

FISH with $18 \mathrm{~S}$ rDNA probe, additionally revealing other nine NOR-bearing chromosomes, comprising 13 detectable sites. On the other hand, in the population from Perdizes stream, the Ag-NORs were visualized at $8^{\text {th }}$ pair and at 1 homologous chromosome from the $19^{\text {th }}$ pair, a result also supported by in situ hybridization with $18 \mathrm{~S}$ rDNA probe, besides other 7 chromosomes, totalling 10 detectable NOR cistrons.

It is possible that the differences related to the location of rDNA sites between both populations is caused by the dispersion of ribosomal genes, involving transpositions of these sites over chromosomes. This kind of rearrangement has been considered one of the most plausible events of NOR variation amongst fishes (Galetti Jr. et al. 1995, Almeida-Toledo et al. 1996, Mantovani et al. 2000, Souza et al. 2001). Thus, the dispersion of ribosomal sites have taken place independently, favoring to the genetic differentiation between both isolated populations of $H$. anisitsi.

Differences involving the position of ribosomal genes in the karyotype, possibly derived by transpositions, were also observed among populations of Astyanax scabripinnis (Mantovani et al. 2000, Souza et al. 2001). In fact, the location of ribosomal sites have showed to be an useful tool in characterizing populations of several fish species (Feldberg et al. 1999, Ferro et al. 2001). In A. scabripinnis, the great karyotypical diversity can be corroborated by allopatry condition amongst species and/or populations, and related to geographical and/or biological isolation (Moreira-Filho and Bertollo, 1991). It should be pointed out that both populations of $H$. anisitsi were collected 

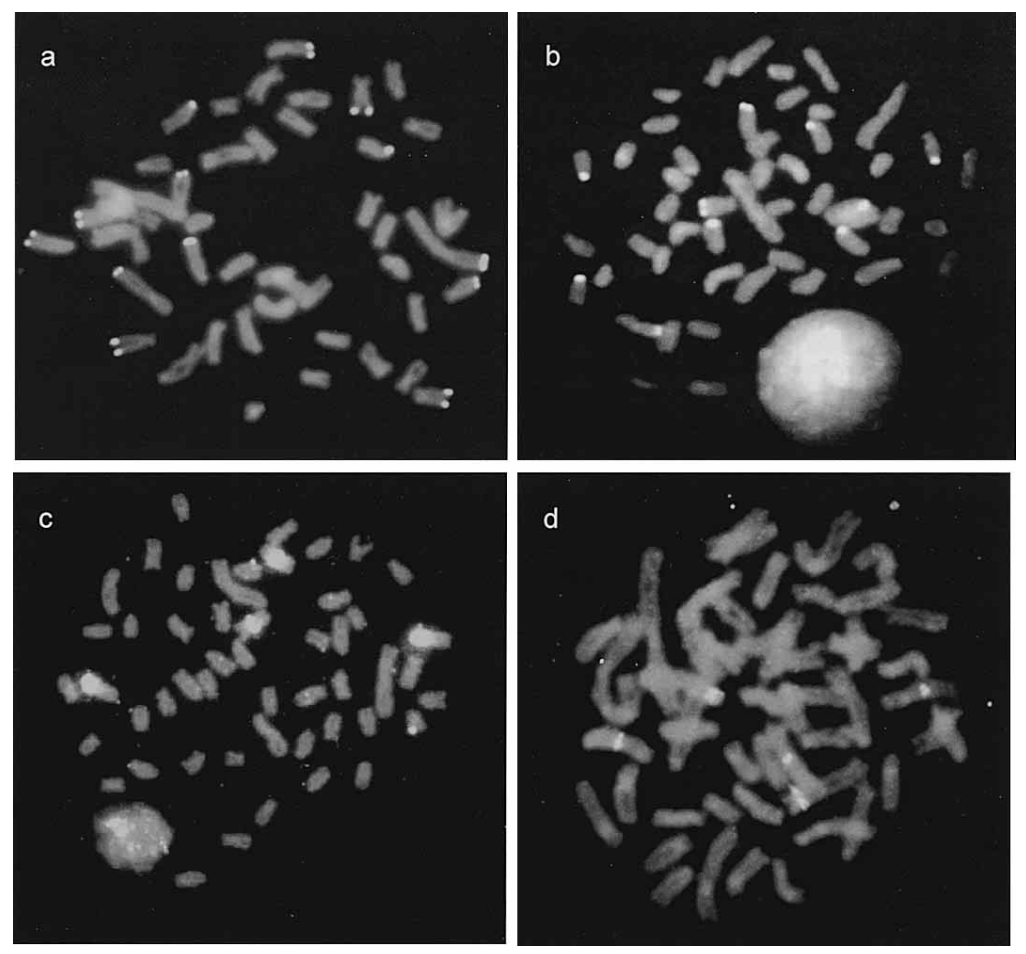

Fig. 3. Fluorescent in situ hybridization showing the localization of $18 \mathrm{~S}$ rDNA sites of Hyphessobrycon anisitsi from, a) Piracuama river, b) Perdizes stream. Fluorescent in situ hybridization showing the localization of 5S rDNA sites of Hyphessobrycon anisitsi from, c) Piracuama river, d) Perdizes stream.

along sympatric populations of $A$. scabripinnis. However, the chromosomal modifications detected in populations of $H$. anisitsi were not as remarkable as those observed among populations of $A$. scabripinnis (Moreira-Filho and Bertollo 1991, Souza and Moreira-Filho 1995, Mantovani et al. 2000, Ferro et al. 2001, Souza et al. 2001) indicating that, albeit under a similar isolation condition, each population/species have undergone a differentiated and peculiar pattern of karyotypical evolutionary pathway.

The ribosomal 5S gene is considered highly conserved (Danna et al. 1996). Because its conservativeness and location over different genome regions, studies about the location of 5S rRNA genes have been used in phylogenetic approaches or as a populational marker (Martins and Galetti Jr. 2001). Previous reports about the organization and/or localization of 5S rDNA amongst fish are available in some species of Acipenseriformes, Anguiliformes, Salmoniformes, Cypriniformes, Perciformes, and Characiformes. The population of $H$. anisitsi from Piracuama river presented four 5S rDNA loci, located at 2 chromosomal pairs, whereas the population from Perdizes stream presented 5 loci, 4 of them probably homeologous to those from the former population. Most of Characiformes species analyzed so far presents up to four 5S rDNA sites, preferentially situated at interstitial region, close to centromere, a putative strategical region for the maintenance and conservation of this gene, since it is less susceptible to chromosomal rearrangements (Martins and Galetti Jr. 2001). Nevertheless, eight 5S rDNA sites were observed in populations of Astyanax scabripinnis (Ferro et al. 2001). The increasing in the number of 5S rDNA sites within populations of $A$. scabripinnis and $H$. anisitsi could be likely correlated to the dispersion of these gene sequences, leading to increased genetic variability of such populations. Abel (2001) suggests that chromosomal alterations would contribute to maintain the genetic variability within isolated populations restricted 
to small water collections, as seen in A. scabripinnis.

Taking into account the distribution of $18 \mathrm{~S}$ and $5 \mathrm{~S}$ ribosomal genes in populations of $H$. anisit$s i$, we can propose that allopatry, determined by a water divisor (Mantiqueira Hills), is playing an important role in the fixation of independent chromosomal rearrangements between both populations. Therefore, despite of a similar karyotypical macrostructure, these populations can be distinguished by a differentiation related to nucleolar organizer regions, indicating a degree of genetic divergence.

\section{Acknowledgements}

The authors are grateful to Dr. Paulo A. Buckup and MsC. Filipe A. G. de Mello (National Museum of Rio de Janeiro) for the taxonomical identification and to CNPq and FAPESP (Proc. 01/00713-0) for financial support.

\section{References}

Abel, L. D. S. 2001. A variabilidade do Complexo de Espécies scabripinnis (Pisces, Characidae) como Estratégia Adaptativa. Estudo da Diversidade Cariotipica do Grupo com Ênfase em Populações da Bacia do Rio São Francisco. Dissertação de Mestrado, Universidade Federal de São Carlos, São Paulo, Brasil.

Ab'Saber, A. N. and Bernardes, N. 1956. Vale do Paraiba, Serra da Mantiqueira e arredores de São Paulo. Eng. Min. Met. 24: 283-292.

Almeida-Toledo, L. F., Bigoni, A. P., Bernardino, G., Foresti, F. and Toledo-Filho, S. A. 1996. Karyotype and NOR conservatism with heterochromatin reorganization in Neotropical Bryconids. Caryologia 49: 35-43.

Arefjev, V. A. 1990. Cytogenetics of aquarium fishes. 3. Problems of karyotypic variability in the family Characidae (Pisces, Characiformes) with the description of somatic karyotypes for 6 species of tetras. Caryologia 43: 305-319.

Bertollo, L. A. C., Takahashi, C. S. and Moreira-Filho, O. 1978. Cytotaxonomic considerations on Hoplias lacerdae (Pisces, Erythrinidae). Brasil. J. Genet. 1: 103-120.

Bohlke, J. E., Weitzman, S. H. and Menezes, N. A. 1978. Estado atual da sistematica dos peixes de água doce da América do Sul. Acta Amazônica 8: 657-677.

Britski, H. A. 1972. Peixes de Água Doce do Estado de São Paulo-Sistemática. In: Poluição e Piscicultura, CIBPU-FSPUSP e IP-CPRN-SA p. 79-108.

Centofante, L., Porto, J. I. R. and Feldberg, E. 2002. Chromosomal polymorphism in Serrasalmus spilopleura Kner 1858 (Pisces, Serrasalminae) from central amazon. Caryologia 55: 37-45.

Dana, K. J., Workman, R., Conyell, V. and Keim, R. 1996. 5S rDNA genes in tribe Phaseoleae: array size, number, and dynamics. Genome 39: 445-455.

Eigenmann, C. H. 1917. The american Characidae. Mem. Mus. Camp. Zool. 53: 1-102.

Feldberg, E., Porto, J. I. R., Santos, E. B. P. and Valentin, C. S. 1999. Cytogenetic studies of two freshwater scianids of the genus Plagioscion (Perciformes, Scianidae) from the central Amazon. Genet. Mol. Biol. 22: 351-356.

Ferro, D. A. M., Néo, D. M., Moreira-Filho, O. and Bertollo, L. A. C. 2001. Nucleolar organizing regions, 18S and 5S rDNA in Astyanax scabripinnis (Pisces, Characidae): populations distribution and functional diversity. Genetica 110: $55-62$.

Galetti Jr., P. M., Mestriner, C. A., Monaco, P. J. and Rasch, E. J. 1995. Post-zigotic modifications and intra- and interindividual nucleolar organizing region variations in fish: report of a case involving Leporinus friderici. Chromosome Res. 3: 285-290.

Howell, W. M. and Black, D. A. 1980. Controlled silver-staining of nucleolus organizer regions with a protective colloidal developer: a 1-step method. Experientia 36: 1014-1015.

Levan, A., Fredga, K. and Sandberg, A. A. 1964. Nomenclature for centromeric position on chromosomes. Hereditas 52: 201-220.

Lima, F. C. T. and Gerhard, P. 2001. A new Hyphessobrycon (Characiformes, Characidae) from Chapada Diamantina, Bahia, Brazil, with notes on its natural history. Ichthyol. Explor. Freshw. 12: 105-114.

Lucena, C. A. S. 1993. Estudos filogenéticos da família Characidae com uma discussão dos grupos naturais propostos (Teleostei, Ostariophysi, Characiformes). Tese de Doutorado, Universidade de São Paulo, São Paulo, Brazil.

Mantovani, M., Abel, L. D. S., Mestriner, C. A. and Moreira-Filho, O. 2000. Accentuated polymorphism of heterochromatin and nucleolar organizer regions in Astyanax scabripinnis (Pisces, Characidae): tools for understanding karyotypic evolution. Genetica 109: 161-168. 
Martins, C. and Gatetti Jr., P. M. 1999. Chromosomal localization of 5S rDNA genes in Leporinus elongatus fish (Anostomidae, Characiformes). Chromosome Res. 7: 363-367.

— and - 2001. Two 5S arrays in neotropical fish species: is it a general rule for fishes? Genetica 111: 439-446.

Moreira-Filho, O. and Bertollo, L. A. C. 1991. Astyanax scabripinnis (Pisces, Characidae): a species complex. Braz. J. Genet. 14: 331-357.

Pinkel, A. M., Straume, T. and Gray, J. W. 1986. Cytogenetics analysis using quantitative, high-sensitivy, fluorescence hybridization. Proc. Nat. Acad. Sci. 83: 2934-2938.

Scheel, J. J. 1973. Fish Chromosome and Their Evolution. Internal Report of Danmarks Akuarium, Charlottenlund, Danmark, $22 \mathrm{p}$.

Souza, I. L., Galian, J., Rúa, P., Bertollo, L. A. C. and Moreira-Filho, O. 2001. Non-random distribution of the GC-rich heterocromatin and nucleolar rDNA sites on Astyanax scabripinnis chromosomes. Citologia 66:85-91.

_ and Moreira-Filho, O. 1995. Cytogenetic diversity in the Astyanax scabripinnis species complex (Pisces, Characidae). I. Allopatric distribution in a small stream. Cytologia 60: 1-14.

Sumner, A. T. 1972. A simple technique for demonstrating centromeric heterochromatin. Expl. Cell Res. 75: 304-306.

Vicente, V. E. 2001. Estudos citogenéticos e moleculares em Parodon hilarii e correlações em outras especies da família Parodontidae (Pisces, Characiformes). Tese de Doutorado, Universidade Federal de São Carlos, SP, Brazil. 